\title{
THE MEMBERSHIP OF A WORLD TRIBUNAL FOR PROMOTING PERMANENT PEACE
}

Ir is generally believed that some kind of an agreement between some, at least, of the different governments of the world, for the better regulation of their mutual relations, must follow the close of the present wars in order most effectively to promote permanent peace. Such an agreement would naturally take the form of a treaty. It is not too soon for all peoples to consider what should be its essential nature. From a state of peace to a state of war is a short step. From a state of war to a state of peace is a long one. Official overtures of a more or less informal character must come first. A preliminary protocol of some kind must then be framed, either with or without a suspension of hostilities. One or more peace conferences naturally follow, to make more definite and permanent arrangements, and their work must practically be ratified by the legislatures of the Powers concerned. Meanwhile public opinion in each of these countries must be considered and clarified. All this takes time, and the most enduring peace is apt to be one that has not been hurried to a conclusion.

It required more than seven years of negotiation to put an end to the Thirty Years' War. Three were spent in feeble and sporadic attempts at a settlement. Four followed which laid, by the Peace of Westphalia, the foundation of modern political history. Meanwhile fighting continued, and with the bitterness which has always characterized wars of religion. The very men who finally agreed on terms of peace met in separate congresses, one Protestant and the other Catholic, one in Münster and the other in Osnabrück.

They would not have agreed on them so soon had not, early in that war, international law been systematized by Grotius. Every treaty rests on public law. The public law of the world is continually growing. Its essential principles are receiving new applications and interpretations from year to year. Their relations to society are shifted. 
New rules are added. Old rules are modified. The treaty that is to end the present wars will relate itself to the public law of the day. And how is it to be determined what this law is? It will, on important points, be for those making that treaty to exercise that power, in behalf of those for whom they act; and, if they exercise it wisely, they may thus permanently affect the course of legal history as to the entire family of nations.

But this family as a whole has a direct interest of its own in whatever belongs to public law. The present wars have shown that there is a grave question whether some of the rules attributed to it have ever existed or, if they once existed, exist now. The restoration of peace will present a great opportunity to restate that law, authoritatively, by general consent.

The restatement of public and of international law would be of the greatest potential value if an agency existed by which, as restated, it could and would be applied to settle future disagreements between nations. The Hague Peace Conferences of 1899 and 1907 made substantial progress in these directions. So did the London Naval Conference of 1908, at which, in 1909, the Declaration of London was framed. We must not allow the advantages thus gained to be lost. Ground once secured must not be surrendered. Half the world met for a friendly interchange of views as to the best way to promote international peace, at the first Hague Conference. All the world met at the second. A new point of departure was thus attained.

Whatever new provisions for the maintenance of peace are devised, they will be most apt to endure if there is some historical foundation on which to rest them. They must be a product of evolution from former rules affecting international relations. These rules are part of the international capital of mankind. It is a capital to be carefully guarded with a view to its gradual increase.

It may be assumed that there will ultimately be either a peace congress to close the present wars, composed of representatives of the leading belligerents on each side, and probably of all the belligerents; or two peace congresses for that purpose: one composed of all the nations which are at war with Germany and her allies, and one representing the latter. The second plan would be that which was adopted 
to close the Thirty Years' War, - two congresses sitting at the same time, and communicating with each other through some sort of mediation. The first plan is the simpler and more direct.

But whichever may be adopted, the main work to be undertaken will be to accomplish a general pacification by common agreement on reasonable terms. The office of a peace congress is to make peace. Whatever more it might effect in defining or improving the public law of the world, or creating new facilities for defining or improving it, could probably be better effected by a congress called specially for that purpose, and proceeding with the deliberation necessarily to be expected from such a body.

It is also true that a peace congress, after bringing a war to a close, can adjourn for a considerable period, to be reconvened as a congress for the settlement of general principles of international conduct. It may be doubted, however, whether a congress of the latter kind, even with large changes in its membership, could ever approach the subject with the freedom from influences occasioned by the war, and the juristic sense and power, that might be expected from a body newly and specially constituted for its consideration.

It is fortunate that we have already a world tribunal, created by a common agreement for the settlement of international disputes, and which has proved its right to exist by what it has already accomplished. The Permanent Court of Arbitration, commonly called the Hague Tribunal, is the work of two peace congresses. As revised in the second, it is the voice of an association of nations universal in character. Notwithstanding the pending wars, its functions continue the same, though for the time being it has not been called on to exercise them. One of its distinctive features is that its members are a panel of between one and two hundred, coming from all nations. Not all sit in every instance. The particular nations which may be parties to a dispute choose each two of the members to constitute with an umpire the tribunal in that particular case. The fundamental requirement here is the absolute equality of the contending nations before the court and in the preparation for the court.

As to the court itself, no one, except the umpire, is eligible as a member unless he be of recognized competency to pass on questions 
of international law and of the highest moral reputation. But as to the governments which choose them there is no distinction. The greatest and the least Powers stand here on the same footing. There is no inquiry into their national characteristics or moral reputation. So long as they are recognized as political sovereigns, they can appeal to the Permanent Court of Arbitration. Their previous records can not serve to exclude them. So long as a political sovereign, party to such a proceeding, selects, through such of its authorities as may be charged by its own laws or institutions with the conduct of its foreign relations, the two judges whom it is entitled to place upon the court, it can not be objected that those authorities were not duly qualified to make the selection.

Should such a body as is now proposed by the League to Enforce Peace come into existence after the present wars, a very different set of considerations would apply to the mode of its organization. Inequality, rather than equality, would, in some things at least, be the guiding principle. It would have the most delicate duties to discharge. It would be a council of nations rather than a court of justice. It would be apt to prove, in essence, something like the Diet of the former German Empire and the later Germanic Confederation, with its power of issuing a "federal execution" against any recalcitrant state. It is not to be forgotten that it was an exercise of that power which finally led to the destruction of the Confederation in 1866.

A bold attempt to plan out such an international assembly for the government of the world was made in 1911 by Mr. Jerome Internoscia of Montreal. It was to consist of one or more delegates from any adhering state, according to its population; to have executive, legislative, and judicial powers; to sit part of the year as a legislature and part as a court; and to be supported by an irresistible military and naval force. Action on all matters was to be determined by a majority vote. This, while a fantastic scheme, is worth mention, because of its fundamental postulate that any state in the world, at all times, must have a right to representation in such an assembly. This, of course, does not proceed from the principle of jurisprudence which guarantees to every one his "day in court." A man charged with some fault before a court can claim, not to be a member of the court, 
but to be heard before it. If assailed there, he must be allowed to defend there. This is a right that belongs even to alien enemies. ${ }^{1}$ It can, in the nature of things, belong no less to a nation and to every nation.

In any international conference that may be convened to plan for putting an end to the present wars, it can hardly be doubted that each of the belligerent Powers will be at least asked to participate. It would seem probable that two such assemblages would be found necessary, one of a preliminary nature, to settle the points of most immediate importance, and one to act finally on all matters remaining unsettled. The latter might be an adjourned session of the first, but would be more likely to be separately constituted. In the first, called to try to create peace, the military questions involved would call especially for consideration by military officers; in the second, called to try to improve international conditions in time of peace, there would be more need of the services of statesmen and jurists.

When, in 1814, the Powers successful in overthrowing Napoleon convoked the Congress of Vienna, while they allowed France to join in the call, they hoped, by a secret agreement made for that purpose, to exclude her from any real voice in the proceedings. France nevertheless claimed an equal voice when the Congress met, and it was conceded to her. It could not have been denied if the Treaty of Vienna was to have any permanent effect on her relations to the other European Powers.

So in the organization of any world tribunal of justice which may follow the present wars (whether it be the present Hague Tribunal, or the Court of Arbitral Justice contemplated by the draft of a convention approved by the Hague Conference of 1907, or something better than either) every civilized nation should have a voice in the international assembly from which it may proceed.

Justice would not demand that it should be an equal voice. Rather it would demand that the small Powers should not have this. Whether the representation of each should be equal in number or unequal, the weight of every vote should be proportioned to the weight of the Power which casts it.

1 Ex parte McVeigh, 11 Wallace, 207. 
In preparing for the Congress of Vienna, Talleyrand wrote and the King adopted instructions to the French ambassadors, from which the following extract is taken:

The general equilibrium of Europe can not be composed of simple elements. It can only be a system of partial equilibrium. The small or medium states should be allowed a vote only in the questions concerning the particular system to which they belong - the states of Italy in the arrangements relative to Italy, and the German states in the arrangements relative to Germany. The great Powers alone, being interested in the whole, should coördinate each part with regard to the whole. ${ }^{2}$

A mode of obtaining the same general result would be to make voting power, in international congresses and courts, relative to population, or to the general magnitude and diversity of interests to be guarded by the greater nations. It was in this way that the congress proceeded which met in 1906 to regulate wireless telegraphy.

It has been suggested that the scheme of successive Hague Conferences, under which two have already been held and a third resolved on, should be replaced by conferences of limited instead of unlimited membership. There is already an association of nations of the first importance headed by Great Britain and France, and another of a like character, though less numerous, headed by Germany and AustriaHungary. Why not make use of these as instruments for the reconstruction of social order in the family of nations? The objections to such a proposition would seem conclusive. Each would be the rival of the other in attracting adherents. Each, whether in court or congress, would add to the natural force of nationality the artificial influences incident to its own existence. There would naturally be two leagues, two courts, two tendencies of thought, two views of public law. Given two leagues, it would be practically impossible not to have two international courts. Given two international courts, and it could hardly be expected that they would always agree on points of international relationship. The continued existence, also, of two powerful alliances, originally formed for purposes of war, would be a constant menace to the peace of the world. The innate character and common experiences of each would at once, or certainly eventually,

2 Broglie, Memoirs of Talleyrand, II, 157, 172.

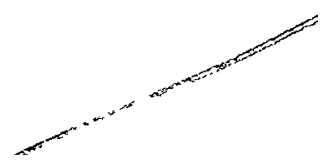


bring a new and positive element of discord into the society of nations. If each alliance maintained an international court, these courts might be expected often to differ in their conclusions. If only one maintained such a tribunal, its judgments would be considered of light weight in countries not in the alliance to which it owed its origin.

There certainly ought to be, in the interests of human society, one standing tribunal of justice for the world. There is one now, though far from perfect, - the Permanent Court of Arbitration. A plan for adding what may prove a better one, the Court of Arbitral Justice, has proceeded from the same source. It may be possible and practicable to adopt some new method, either independent or supplemental, of attaining the desired end that is better than either or both. But it will only be if all civilized nations are asked to send delegates to the conference which devises that method, and probably not unless membership in the new tribunal is made open to all citizens of each on terms that give every country such weight of choice as its relative importance fairly merits.

The Hague Convention of 1907 for the creation of an International Prize Court, which failed of ratification, followed in most particulars these general principles. Its scheme, however, in securing on a bench of fifteen judges eight places for the great Powers, the others being filled by the lesser Powers in rotation or by lot, did not satisfy the views of the latter as to equity or right. The distinction between the two classes of Powers was deemed to be too pronounced.

Questions of this kind will be less easy to answer if a new world court is established with powers of physical coercion. The greater such powers, the harder it will be to agree on the method of choosing those to whom they are to be intrusted.

To the writer the objections to enforcing compliance with the orders of any world tribunal by its active use of a military and naval establishment seem insuperable under the conditions that will immediately follow the restoration of peace. The existing feelings of emnity between the peoples of the contending Powers will be too strong. Time only can conquer them. It may well be doubted if that would ever bring the world together as a fighting force to compel any particular sovereign to obey the decrees of such a tribunal. - There well might, 
however, be an agreement to resort to international outlawry, or, in some other way, to use economic and social pressure under such circumstances, which would command general consent.

Wherever there can be instituted, by order of an international court, a state of what would amount to "imperfect war," the court would be kept filled with generals and admirals. A court of justice ought to have a bench of jurists.

It ought also to be such as to entitle it to be looked to as a court of honor. It must stand and prove its right to stand as an Ehrengericht, whose decisions can not be disregarded by honorable men, whether acting for themselves or for nations. Its real charter must proceed from public opinion.

Its members should be above reproach or suspicion of reproach. They should be originally selected only after painstaking inquiry as to their position and character.

Had the appointments of the American members of the present Hague Tribunal been submitted to the Senate for ratification, it would have given a public guaranty of their fitness for such a position, which would have been justly regarded by other nations as of high importance. Still more would such a mode of procedure be of value should any such court of arbitral justice with a small and definite membership be organized as was proposed by the Hague Conference of 1907 .

Another possibility in world reconstruction which deserves consideration in this connection is the formation of a confederation of nations with power to judge between them, but whose judgments should be enforceable only according to the determination of another and distinct tribunal. The confederation might decide that one of its members had committed or was threatening to commit some act in breach of its international duties, and then it might be reserved for some kind of executive council to promulgate and execute the judgment.

In mediæval Germany disputes between the states of the Empire had come to be generally regarded as proper subjects of arbitration. The arbitrators (Austregues) were commonly agreed on by the states concerned, sometimes chosen by lot. The Diet of Worms, in 1495, framed what it deemed a better plan to preserve perpetual peace within 
the Empire. ${ }^{3}$ This provided that if any party to such an arbitration did not accept the decision as final, it might appeal to a standing Imperial Chamber of Justice (Reichskammergericht), composed of seventeen judges, proceeding according to the principles of the Roman law; but that the judgments of the Chamber were only to be executed as and when an Imperial Council (Reichsregiment) might determine. A. few years later this function was confided to "circles" of neighboring states, and the Imperial Council soon gave way to the Aulic Council, a mere mouthpiece of the Emperor.

Hamilton, in the Federalist (No. LXXX), in urging the necessity of securing the peace of the United States by a judicial determination of controversies between the States of the Union, spoke of the institution of this Imperial Chamber of Justice, in 1495, as a wise and successful measure.

Under any such plan (whether a previous resort to arbitration should be required, or not) the body which was to speak first as a regular court of justice would naturally be composed of jurists and publicists, for their office would be to settle rights. The other body would be largely concerned with functions of policy and expediency. It might be of opinion that the case was governed by the principle, Summum jus, summa injuria, and so refuse to issue an execution. It might believe the judgment to be right on all points and yet decline to take any action. A council with authority to act in such a manner would be mainly executive in character. Its members, therefore, would naturally be men of affairs rather than of books.

There are those who would exclude from a share in framing a world tribunal for promoting permanent peace any state which is in a marked degree inferior to most of the other Powers as respects the education and general cultivation of its people. Such a test is one difficult to apply and invidious in its nature. It might result in a discrimination that would bar out Powers of large population and extensive trade, though they have political leaders of the highest rank for learning, wisdom, and character. A body to promote the peace of the world can not safely be founded on principles of inequality and exclusion.

Simeon E. BaLdWIN.

3 Robertson, History of Charles V, I, 359; Hallam, Middle Ages, 306; Snow, Report of the Am. Society for Judicial Settlement of International Disputes for 1916, 47. 